\title{
Illness Perception as a Predictor of Health-related Quality of Life in Patients with End Stage Renal Disease: Comparison between Haemodialysis and Continuous Ambulatory Peritoneal Dialysis Patients
}

(Persepsi terhadap Penyakit sebagai Peramal kepada Kualiti Hidup Kesihatan Pesakit Buah Pinggang Tahap Akhir: Perbandingan antara Pesakit Hemodialisis dan Dialisis Peritoneum Ambulatori Berterusan)

\author{
NORHAYATI IBRAHIM*, NORELLA KONG CHIEW THONG, ASMAWATI DESA \& ROZMI ISMAIL
}

\section{ABSTRACT}

This cross-sectional study examined the influence of illness perception of health-related quality of life (HRQoL) in end stage renal disease (ESRD) patients on either hemodialysis (HD) or continuous ambulatory peritoneal dialysis (CAPD). The Short Form-36 (SF-36) was used to measure HRQoL which comprised the Physical Component Summary (PCS) and Mental Component Summary (MCS). Illness perception was evaluated using Revised Illness Perception Questionnaire (IPQ-R). Both questionnaires were administered on 183 HD and 93 CAPD patients. The results showed that almost all HRQoL subscales except physical functioning and bodily pain were found to be significantly different between HD and CAPD patients. There are significant correlations between most components of illness perception with HRQoL. Significant illness perception predictors of PCS among HD patients were time line, consequences, cyclical and identity, whereas on CAPD patients were time line, illness coherence, emotional, cyclical and identity. Significant illness perception predictors of MCS among HD patients included time line, cyclical and identity and only time line was significant predictor of MCS on CAPD patients. These should be considered when developing intervention programmes to improve their HRQoL.

Keywords: Continuous ambulatory peritoneal dialysis; end-stage renal disease; haemodialysis; health-related quality of life; illness perception

\section{ABSTRAK}

Kajian keratan rentas ini bertujuan meneliti pengaruh persepsi terhadap penyakit terhadap kualiti hidup kesihatan dalam kalangan pesakit buah pinggang tahap akhir yang menjalani rawatan hemodialisis (HD) and dialisis ambulatori peritoneum berterusan (CAPD). Alat ujian SF-36 telah digunakan untuk mengukur kualiti hidup kesihatan yang mengandungi komponen fizikal dan mental. Sementara itu, persepsi terhadap penyakit pula diukur menggunakan Soal Selidik Persepsi Penyakit Terpinda (IPQ-R). Kedua-dua alat ujian tersebut telah ditadbirkan ke atas 183 pesakit HD and 93 pesakit CAPD. Keputusan kajian menunjukkan bahawa hampir kesemua subskala kualiti hidup kesihatan kecuali kefungsian fizikal dan kesakitan badan didapati berbeza secara signifikan bagi pesakit HD dan CAPD. Kebanyakan komponen persepsi terhadap penyakit berkorelasi dengan kualiti hidup kesihatan pesakit. Komponen persepsi terhadap penyakit yang menjadi peramal kepada kualiti hidup kesihatan fizikal bagi pesakit hemodialisis ialah had masa, kesan, kitaran dan identiti. Sementara pemboleh ubah peramal bagi komponen kualiti hidup kesihatan mental bagi pesakit CAPD ialah had masa, koheren penyakit, emosi, kitaran dan identiti. Peramal yang signifikan ke atas kualiti hidup kesihatan komponen mental bagi pesakit HD termasuk had masa, kitaran dan identiti. Walau bagaimanapun hanya had masa sahaja yang menjadi peramal ke atas kualiti hidup kesihatan komponen mental bagi pesakit CAPD. Sehubungan itu sebarang program intervensi ke atas pesakit tersebut perlu memberi penekanan kepada beberapa pemboleh ubah persepsi terhadap penyakit bagi meningkatkan kualiti hidup pesakit.

Kata kunci: Dialisis ambulatori peritoneum berterusan; hemodialisis; kualiti hidup kesihatan; persepsi terhadap penyakit; pesakit buah pinggang tahap akhir

\section{INTRODUCTION}

Health-related quality of life (HRQoL) issues are of increasing concern to healthcare researchers. Previous studies found that HRQol of end stage renal disease (ESRD) patients were low and unsatisfactory (de Wit et al. 2001; Klang et al. 1996; Korevaar et al. 2000; Walters et al. 2002). In fact, the quality of life (QoL) has also become an indicator of mortality and hospital admissions. For example, studies by Curtin et al. (1999), Mapes et al. (2003) and Rumsfeld et al. (1999) found that the decline of QoL increased the risk of death among dialysis patients. HRQoL was discrupted due to various pressures including lifestyle changes, physical activity, a limited social life and an uncertain future. (Blodgett 1981; Sensky 1993). Other 
researchers also found that these patients were repeatedly experienced a low level of activity, sexual problems and difficulty in maintaining their jobs (Lok 1996; Merkus et al. 1997).

Dialysis modality and QoL have been studied intensively for the past decade. Some studies found that the dialysis modality could influence QoL but others did not. For example, Gokal et al. (1999) and Majkowicz et al. (2000) reported that CAPD patients had better QoL compared with HD patients. Whereas Mittal et al. (2001) and Wasserfallen et al. (2004) found no differences between the two types of dialysis. Meanwhile, Griffin et al. (1994) found that HD patients experienced more pain, more discomfort and more serious disease symptoms compared with their CAPD counterparts.

Previous study results were highly inconsistent -some researchers found that the QoL of HD patients was worse compared to those on CAPD, whereas others observed no difference in the QoL based on treatment modality. Obviously other factors must have contributed to these findings. Kalander et al. (2007) reported that the different of QoL based on dialysis modality could be explained by differences in socio-demographic characteristic, patients' clinical features or the methods used to measure the QoL. Hence none of the findings reported to date could be generalised to ESRD patients in other societies or geographic locations.

According to Timmers et al. (2008), perception toward illness is related to patients' QoL. They found that compared with HD patients, CAPD patients experienced more personal control and had a better understanding of their illness. Illness perceptions explained some 17 to $51 \%$ of the variance in QoL scores in various studies. Perception of more symptoms, more consequences and lower personal control were associated with lower wellbeing. This parallels the view of the common-sense model whereby the individual's perception towards illness affected his/her preconception of their disease (Diefenbach \& Leventhal 1996). Patients usually having their own beliefs of their disease and they make plans based on their beliefs (Hagger \& Orbell 2005). In fact, some patients who attended the treatment have built a negative perception of their situation, which contributed to their increased concern and worries (Fowler \& Baas 2006). On the other hand, some studies showed that when patients had negative perceptions of their disease, these perception continued for prolonged periods (Timmers et al. 2008). Such negative belief would delay the recovery process (Scharloo et al. 2000, 1999). Illness perception then becomes the determinant of behaviour and impacts significantly on treatment, strength, recovery (Leventhal et al. 1997) and patient's QoL (Fowler \& Baas 2006; Timmers et al. 2008). Hence, the goal of this study was to identify the influences of illness perception on patients' HRQoL and to determine those components which predict the HRQoL of patients undergoing chronic HD and CAPD treatments.

\section{METHODS}

\section{PARTICIPANTS}

Participants were chronic end-stage renal disease (ESRD) who attended facilities affiliated with the Universiti Kebangsaan Malaysia Medical Centre (UKMMC), MAAMedicare Charity Fund Dialysis Centre and the Batu Pahat Specialist Hospital. This study involved 274 patients with 183 undergoing HD and 91 CAPD. ESRD patients who met the following criteria: On chronic maintenance HD or CAPD; Age 18- 75 years; Malay or English speaking; and gave informed consent were included in this study. Patients who had been on dialysis less than 3 months and those who had communication difficulties were excluded.

\section{PROCEDURE}

Upon approval from the UKMMC Scientific Research and Ethical Committe, subjects who met the criteria and gave informed consent were interviewed individually by the researcher. HD patients were interviewed when they were undergoing their $4 \mathrm{~h}$ treatment. CAPD patients were interviewed whilst they were waiting in the clinic for review by their doctors/ trainee nurse. Patients were assesed using the Short Form 36 (SF-36) and Illness Perception Questionnaire- Revised (IPQ-R).

\section{MEASURES}

Short Form - 36 (SF-36) Quality of life was assessed using the Short Form-36 (SF-36). The SF-36 evaluates various aspects of functioning and well-being so as to provide an overall impression of HRQoL and was developed as the best compromise between response burdens. It is a generic self- completed questionnaire with eight dimensions. These eight dimensions include physical functioning, physical role limitation, emotional role limitation, social functioning, pain, mental health, vitality and general health perception. These contribute to the evaluation of two major aspects of patients' functioning - physical (physical component summary, PCS) and mental (mental component summary, MCS) (Ware et al. 1993). It takes about 15 min to answer the questions. Scoring is by summing the responses for each of the items in the dimensions and converting them by a scoring algorithm to a scale from 0 (poor health) to 100 (good health). A higher score indicates better functioning, less pain or greater well-being. The reliability of SF-36 was assessed by Norhayati et al. (2011) and demonstrated excellent consistency with Cronbach's alpha values of 0.65 to 0.89 .

Revised Illness Perception Questionnaire (IPQ-R) Illness perception was assessed with the well-validated Revised Illness Perception Questionnaire developed by MossMorris et al. (2002). The IPQ-R assesses nine components of illness representation in three sections. The first section asks about the subscale Identity - in which participants are asked yes/no questions about 18 different symptoms 
and whether they believe these symptoms to be related to being on HD. The second section consists of 38 questions which address seven subscales - time-line, cyclical (nature), consequences, personal control, treatment control, coherence and emotional response. The patients rate the items on a five-point scale (likert scale), ranging from 'strongly disagree' to 'strongly agree'. The Time-line dimension is assessed by six items. A high score on this dimension indicates the patient's perception of the chronic course of the disease. Cyclical is assessed by four items whereby patients view their illness as episodes that come and go over time. The Consequence dimension is assessed by six items and a high score indicates that the patient considers the disease as having serious consequences upon his/her life. Personal control dimension assessment comprises five items and a high score indicates the perception of better personal control of the disease.

Treatment control is assessed by five items and a high score indicates that the patient considers HD to be efficient in controlling ESRD. Coherence is a measure of how well the patient understands theirillness. It is evaluated by five items - a higher score indicates the patient's increased understanding of ESRD. The last dimension assesses Emotional response and has six items. A higher score in this dimension indicates more intense emotional reaction to the disease. The final section focuses on the subscale Causes. This scale consists of 18 possible causes for being on dialysis (e.g., lifestyle, hereditary factors, chance, behaviour, uncertainty). This scale also uses the five point Likert scale. The reliability of IPQ-R was measured in Malaysian ESRD patients and found that all illness perception subscale demonstrated adequate reliability which alpha value more than 0.70 except for the treatment control subscale with lower reliability (0.51)(Norhayati et al. 2011).

\section{RESULTS}

A total of 274 ESRD patients on chronic dialysis were recruited - $183(66.8 \%)$ of the patients were on HD and the remaining $91(33.2 \%)$ on CAPD. Of the 183 HD patients,
$54.1 \%$ were males and $45.9 \%$ female. There were $40.4 \%$ Malays, $44.8 \%$ were Chinese and $14.7 \%$ others. Most of the HD patients $(36.6 \%)$ were in the age group between 46 and 55 years. Most of the patients aged between 56-65 (33.9\%), 16.4\% between 23-45 and the remaining $13.1 \%$ were over 65. Most of the HD patients were unemployed and had no pensions (39.4\%), 20.8\% were unemployed with pension and the remaining $20.2 \%$ were still working. A quarter $(38.8 \%)$ of HD patients were on dialysis less than 36 months (3 years), 42.1\% for 36-120 months (3-10 years) and the remaining $19.1 \%$ more than 120 months (>10 years).

Of the 91 CAPD patients, $46.2 \%$ were male and $53.8 \%$ were female. Majority of CAPD patients were Malay $(67.0 \%), 30.8 \%$ were Chinese and the remaining $2.2 \%$ were others. Most of the CAPD patients ages between 23-45 (42.9\%), 20.9\% age between $46-55$ and $24.2 \%$ between 56-65 and the remaining $12.1 \%$ were above 65 . Most of the CAPD patients were unemployed and had no pensions $(50.5 \%), 13.2 \%$ were unemployed with pension and the remaining $36.3 \%$ were still working. Majority of CAPD patients were on dialysis $(74.7 \%)$ for less than 36 months (3 years) and $25.3 \%$ for $36-120$ months (3-10 years).

Almost all HRQoL subscales except physical functioning and bodily pain were found to be significantly different between HD and CAPD patients, with physical role $(t=13.19, p<0.01)$, general health $(t=2.95, p<0.01)$, vitality $(t=-2.43, p<0.01)$, social functioning $(t=-2.38, p<0.01)$, emotional role $(t=-2.11, p<0.01)$ and mental health $(t=2.90$, $p<0.01]$. Based on mean CAPD patients had better scores in physical role, general health, vitality, social functioning, emotional role and mental health compared to HD patients. The results for 2 major subscales of HRQoL which are PCS $(t=-3.46, p<0.01)$ and MCS $(t=-3.05, p<0.01)$ also showed that CAPD patients had better HRQoL compared to HD patients (Table 1).

HD patients had a higher level of perceiving their disease as chronic compared with those on CAPD $(t=4.63$, $p<0.01)$. HD patients also had higher scores in cyclical $(t=3.91, p<0,01)$ and identity $(t=3.07, p<0.01)$ compared with CAPD patients. However CAPD patients had higher

TABLE 1. Comparison of the health related quality of life components between HD and CAPD patients

\begin{tabular}{llcccc}
\hline & \multicolumn{2}{c}{ HD $(n=183)$} & \multicolumn{2}{c}{ CAPD $(n=91)$} & $\mathrm{t}$ \\
& Mean & SD & Mean & SD & 0.24 \\
Physical functioning & 72.568 & 18.151 & 75.275 & 17.307 & $-3.19^{* *}$ \\
Physical role & 68.443 & 19.778 & 76.786 & 21.616 & -2.79 \\
Bodily pain & 74.069 & 22.339 & 81.818 & 20.146 & $-2.95^{* *}$ \\
General health & 58.557 & 15.538 & 64.396 & 15.238 & $-2.43^{* *}$ \\
Vitality & 60.223 & 19.770 & 66.026 & 15.847 & $-2.38^{* *}$ \\
Social functioning & 77.322 & 21.533 & 83.516 & 17.344 & $-2.11^{* *}$ \\
Emotional role & 74.954 & 21.743 & 80.952 & 22.848 & $2.90^{* *}$ \\
Mental health & 71.038 & 19.435 & 78.022 & 17.377 & $-3.46^{* *}$ \\
PCS & 68.42 & 13.71 & 74.57 & 14.24 & $-3.05^{* *}$ \\
MCS & 70.88 & 16.75 & 77.13 & 4.44 & \\
\hline
\end{tabular}

$* p<0.05, * * p<0.01$ 
scores on personal control $(t=-3.26, p<0.01)$. While illness coherence, emotional, consequences, treatment control and disease causes on the subscale were not different between the two patient groups (Table 2).

The results from Table 3 shows that all subscales of illness perception significantly correlated with PCS and MCS except for treatment control with PCS. However, the correlations with time line, cyclical consequences, emotional response, causes and identity were in a negative direction. Thus patients who perceived their illness to be of a chronic and cyclical nature (comes and goes over time) had low PCS and MCS. Patients who perceived their disease as having serious consequences also had lower PCS and MCS. On the other hand, patients with a lower emotional response to their disease attained a better PCS and MCS. Patients who perceived more symptoms and causes related to their illness also had a lower PCS and MCS.

However, there was a positive association between personal control and illness coherence components with PCS and MCS. Patients who scored higher on personal control and illness coherence had a better PCS and MCS. Treatment control significantly correlated with MCS but not with PCS. The positive correlation means that patients who believed that treatment could control their illness had a better quality of life (Table 3 ).
Regression analysis using the entry method was conducted to examine the contributions of illness perception subscales (time line, cyclical, illness coherence, personal control, emotional, consequences, treatment control, causes and identity) on HRQoL (Table 4). Significant illness perception predictors of PCS in HD patients included time line, cyclical, consequences and identity. These factors contributed $35 \%$ of the variance in PCS $\left(r^{2}=0.35, F=10.38\right.$ $p<0.01)$. Significant illness perception predictors of MCS in HD patients included time line, cyclical, illness coherence, emotional and identity. These variables contributed $33 \%$ of the variance in MCS $\left(r^{2}=0.33, F=9.47 p<0.01\right)$. Significant illness perception predictors of PCS on CAPD patients included time line, cyclical and identity. These factors contributed $41 \%$ of the variance in PCS $\left(r^{2}=0.41, F=6.22\right.$ $p<0.01)$. Only time line subscale was predictor of MCS in CAPD patients. This factor contributed $34 \%$ of the variance in $\operatorname{MCS}\left(r^{2}=0.34, F=4.61 p<0.01\right)$.

\section{DISCUSSION}

The results showed that all subscales of HRQoL between patients on HD and CAPD treatment were significantly different except for the subscale of physical functioning and bodily pain. The PCS and MCS of CAPD patients were much better than those of their HD counterparts. These

TABLE 2. Comparison of illness perception components between HD and CAPD patients

\begin{tabular}{lrrrrc}
\hline & \multicolumn{2}{c}{ HD $(n=183)$} & \multicolumn{2}{c}{ CAPD $(n=91)$} & $\mathrm{t}$ \\
& Mean & SD & Mean & SD & $4.63^{* *}$ \\
\hline Time line & 23.94 & 4.91 & 20.91 & 5.45 & $3.91^{* *}$ \\
Cyclical & 9.75 & 2.87 & 8.32 & 2.86 & -0.30 \\
Illness coherence & 16.03 & 4.49 & 16.20 & 4.11 & $-3.26^{* *}$ \\
Personal control & 16.02 & 3.64 & 17.47 & 3.12 & -1.82 \\
Emotional & 12.07 & 4.13 & 13 & 3.67 & 1.34 \\
Consequences & 18.27 & 4.14 & 17.58 & 3.78 & 0.84 \\
Treatment control & 7.98 & 1.63 & 7.81 & 1.28 & 1.79 \\
Causes & 49.51 & 10.79 & 47.11 & 9.66 & $3.07^{* *}$ \\
Identity & 8.84 & 3.96 & 7.22 & 4.44 & \\
\hline
\end{tabular}

$* p<0.05, * * p<0.01$

TABLE 3. Correlation between illness perception with PCS and MCS

\begin{tabular}{lcc}
\hline Variables & PCS $(n=274)$ & MCS $(n=274)$ \\
& $\mathrm{r}$ & $\mathrm{r}$ \\
\hline Time line & $-.22^{* *}$ & $-.26^{* *}$ \\
Cyclical & $-0.37^{* *}$ & $-.27^{* *}$ \\
Illness coherence & $0.31^{* *}$ & $.34 * *$ \\
Personal control & $0.21^{* *}$ & $.20^{* *}$ \\
Consequences & $-0.31^{* *}$ & $-.34^{* *}$ \\
Treatment control & 0.09 & $0.12^{*}$ \\
Emotional & $-0.29^{* *}$ & $-0.34^{* *}$ \\
Causes & $-0.23^{* *}$ & $-0.19^{*}$ \\
Identity & $-0.40^{* *}$ & $-0.35^{* *}$ \\
\hline
\end{tabular}

$* p<0.05, * * p<0,01$ 
TABLE 4. Predictors of PCS and MCS

\begin{tabular}{|c|c|c|c|c|c|c|c|c|}
\hline \multirow[b]{3}{*}{ Variables } & \multicolumn{4}{|c|}{ PCS } & \multicolumn{4}{|c|}{ MCS } \\
\hline & \multicolumn{2}{|c|}{$\mathrm{HD}(n=183)$} & \multicolumn{2}{|c|}{ CAPD $(n=91)$} & \multicolumn{2}{|c|}{$\mathrm{HD}(n=183)$} & \multicolumn{2}{|c|}{ CAPD $(n=91)$} \\
\hline & $\mathrm{B}$ & $\mathrm{t}$ & $\beta$ & $\mathrm{t}$ & $\beta$ & $\mathrm{t}$ & $\beta$ & $\mathrm{t}$ \\
\hline Time line & -0.41 & $-2.23 * *$ & -0.56 & $-2.28 * *$ & -0.59 & $-2.61 * *$ & -0.79 & $-3.03 * *$ \\
\hline Cyclical & -0.81 & $-2.66 * *$ & -1.86 & $-3.61 * *$ & -0.87 & $-2.22 * *$ & -0.67 & -1.23 \\
\hline Illness coherence & 0.43 & 1.89 & 0.48 & 1.31 & 0.77 & $2.74 * *$ & 0.37 & 0.94 \\
\hline Personal control & 0.25 & 1.03 & 0.68 & 1.56 & 0.14 & 0.47 & 0.84 & 1.83 \\
\hline Emotional & -0.24 & -0.95 & -0.69 & -1.69 & -0.64 & $-2.03 * *$ & -0.81 & -1.86 \\
\hline Consequences & -0.66 & $-2.76 * *$ & 0.70 & 1.82 & -0.56 & -1.88 & 0.14 & 0.34 \\
\hline Treatment control & 0.27 & 0.52 & 0.51 & 0.44 & 0.78 & 1.19 & 1.51 & 1.25 \\
\hline Causes & -0.09 & -0.16 & 0.28 & 1.96 & 0.02 & 0.15 & 0.20 & 1.34 \\
\hline Identity & -0.81 & $-3.33 * *$ & -0.82 & $-2.49 * *$ & -0.81 & $-2.68 * *$ & -0.49 & -1.44 \\
\hline $\mathrm{F}$ & $10.38 * *$ & & $6.22 * *$ & & $9.47 * *$ & & $4.61 * *$ & \\
\hline$r^{2}$ & 0.35 & & 0.41 & & 0.33 & & 0.34 & \\
\hline
\end{tabular}

${ }^{*} p<0.05, * * p<0.01$

findings concurs with those of previous studies which demonstrated that patients undergoing CAPD treatment had better HRQoL compared with those on HD (Gokal et al. 1999; Majkowicz et al. 2000; Norshad et al. 2009; Russo et al. 2010).

There are several factors that contribute to the superior HRQoL of CAPD patients. Compared with CAPD, patients who received HD were bound to tight treatment schedules that require them to attend to the hospital or dialysis centers to undergo treatment for blood cleansing for the period of 3 times a week as long as $4 \mathrm{~h}$ per session (Nolph 1996). This situation would limit patients' movement and activities. Through CAPD treatment method, dialysis solution exchange should be done as many as 4 or 5 times per day, depends on patient's life style. However, since it can be carried out alone at home, at workplace or when holidaying, it facilitates patients to go through their lives more freely. In fact, while the dialysis solution is still inside the peritoneal cavity, patients are free to do common daily activities such as cooking, tidying up the house and other light activities. Therefore, CAPD patients have higher levels of involvement in community and in vocational activities (Wolcott et al. 1988). CAPD patients are able to get involved in social and recreational activities and are doing better in employment activities compared with patients who received HD treatment (Tucker et al. 1991).

As HD treatment is carried out three times a week, 4 $\mathrm{h}$ each session, the cyclical nature of the HD may cause HD patients to perceive their disease as more chronic with no personal control. Whereas CAPD patients perform four PD bag changes four times a day by themselves and at time and places suited to them. This gives them greater flexibility and mobility since they are not physically 'tied' to a machine for $4 \mathrm{~h}$ in each treatment session such as HD. This gives CAPD patients a greater sense of personal control. This shows that the types of dialysis treatment greatly influence their HRQoL. Not all patients are given the freedom to choose their dialysis modality. Many factors have to be considered in ascertaining treatment suitability received by the patient. Other than identifying patients' physical and medical factors, psychosocial as well as economic factors are also vital. In particular, the patients' motivation, personal care, lifestyle, educational background, health belief, support system from family and community, their capability in decision-making, medical complications, distance to dialysis centre, housing features (from the aspects of cleanliness, water, electricity supply, telephone and storage space for items related to CAPD treatment ) and capability of spouse, relatives, parents and friends to assist when required (Holloway et al. 1999).

Almost all illness perception subscales were significantly correlated with PCS and MCS except for treatment control with PCS. This finding supports the common-sense model in identifying illness perceptions of patients with chronic disease and the relationship between these perceptions and the outcome in the meta-analysis reported by Hagger and Orbell (2003). This present study also found that illness perception was associated with PCS and MCS but only a few subscales were good predictors for HRQoL. Time line was a predictor for PCS and MCS in CAPD and HD patients. Cylical and identity were predictors for PCS and MCS in both HD and CAPD patients. However consequences subscale can only predict PCS in HD and emotional response subscale only can predict MCS in HD. Some of these findings are consistent with those of Timmers et al. (2008) who found that Illness identity showed significant negative contributions to most outcome areas. Consequences and emotional representations subscales were more strongly associated with some of the outcome measures. However Timmers et al. (2008) found that time line and cyclical did not contribute to the outcome. Whereas this study showed that time line and cyclical were predictors for PCS and MCS. These differences results may be due to cultural factors. Timmers et al. (2008) did the study on patients in Nertherland, whereas this study was carried out in Malaysian patients. Holaday (1989) has demonstrated that the individual's reaction to illness is influenced by the knowledge of the individual, his/her 
ability to face the situation, background life experience and socio-cultural background.

Cultural researchers found that the basic difference in the belief of illness depended on whether the culture is sociocentric and egocentric. For sociocentric cultures, which is prevalence in most societies in Asia, native Americans, Latin America and central America, there are little or no differences between self and others, mind and body, humans and environment and also science and spirituality. In contrasts to egocentric cultures, such as European and North America societies, they construe a separateness, or dualism with emphasis on the individual. Differences of view between these two cultures directly influence beliefs on health and disease (Fabrega 1974; Landrine \& Klonoff 2001).

\section{CONCLUSION}

In conclusion, the types of treatment and patient's perception to illness significantly impact patients' HRQoL. Hence, medical practitioners should include these aspects in order to improve ESRD patient's HRQoL. As state earlier, dialysis treatment itself cannot ensure patients' ability to experience a better life due to the constraints of the disease and the treatment itself. As such, patients' early exposure to this disease and knowledge about the disease and treatment may help them in improving or controlling themselves, improve their adaptation to stress experienced as a result of that disease and consequently undergo appropriate psychological adaptation.

However, this study had some limitations. Being a cross sectional study it could not detect changes in perception towards illness at different time point. Decline or improvement of the HRQoL due to the variables studied could not be identified thus limiting the information available to the researchers. Given these preliminary findings, future longitudinal, and interventional studies are indicated since both have the ability to explain illness perception more precisely and thus help improve patient's HRQoL.

\section{ACKNOWLEDGMENTS}

We would like to thank all the patients who agreed to participate in our study. We are also very thankful to all the doctors and nurses who helped us to collect the data and retrieve the medical records. This study is funded by grant code no: GGPM-2012-100.

\section{REFERENCES}

Blodgett, C.A. 1981. Selected review of the literature of adjustment to hemodialysis. Int. J. Psychiatry Med. 11(2): 97-124.

Curtin, R.B., Lowrie, E.G. \& DeOreo, B.B. 1999. Self-reported functional status: An important predictor of health outcomes among end-stage renal disease patients. Adv. Ren. Replace. Ther. 6(2): 133-140.

de Wit, G.A., Merkus, M.P., Krediet, R.T. \& de Charro, F.T. 2001. A comparison of quality of life of patients on automated and continuous ambulatory peritoneal dialysis. Peritoneal Dialysis International 21(3): 306-312.

Diefenbach, M.A. \& Leventhal, H .1996. The Common-sense model of illness representation: Theoretical and practical consideration. Journal of Social Distress and the Homeless 5(1): 11-38

Fabrega, H. 1974. Disease and Social Behavior. Cambridge, MD: MIT Press.

Fowler, C. \& Baas, L.S. 2006. Illness representations in patients with chronic kidney disease on maintainance Hemodialysis. Nephrology Nursing Journal 33(2): 173-187.

Gokal, R., Figueras, M. \& Olle, A. 1999. Outcomes in peritoneal dialysis and hemodialysis. Nephrol. Dial. Transplant 14(6): 24-30.

Griffin, K.W., Wadhwa, N.K., Friends, R., Suh, H., Howell, N., Cabralda, T., Jao, E., Hatchett, L.A. \& Eitel, P.E. 1994. Comparison of quality of life in hemodialysis and peritoneal dialysis patients. Advances in Peritoneal Dialysis 10: 104108.

Hagger, M.S. \& Orbell, S. 2005. A confirmatory factor analysis of the revised illness perception questionnaire (IPQ-R) in cervical screening context. Psychology and Health 20(20): 161-173.

Hagger, M.S. \& Orbell, S. 2003. A meta-analytic review of the common-sense model of illness representations. Psychology and Health 18(2): 141-184.

Holaday, B. 1989. The family with a chronically ill child. In Toward a Science in Family Nursing, edited by Gilles, C.L. New York: Addison-Wesley.

Holloway, M.S., Blagg, C.R. \& Smoke-Hill, S. 1999. Peritoneal dialysisi and home dialysis therapies. In Review of Hemodialysis for Nurses and Dialysis Personnel, edited by Gutch, C.F., Stoner, M.H. \& Corea, A.L. Missouri: Mosby. p. 230.

Kalander, B., Ozdemir, A.C., Dervisoglu,E. \& Ozdemir, O. 2007. Quality of life in chronic kidney disease: Effects of treatment modality, depression, malnutrition and inflammation. Int. J. Clin. Pract. 61(4): 569-576.

Klang, B., Bjorvell, H. \& Cronqvist, A. 1996. Patients with chronic renal failure and their ability to cope. Scandinavian Journal of Caring Science 10(2): 89-95.

Korevaar, J.C., Jansen, M.A.M., Merkus, M.P., Dekker, F.W., Booeschoten, E.W. \& Krediet, R.T. 2000. Quality of life in pre-dialysis and stage renal disease patients at the initiation of dialysis therapy. Peritoneal Dialysis International 20: 69-75.

Landrine, H. \& Klonoff , E.A. 2001. Cultural Diversity and Health Psychology. Mahwah, NJ: Lawrence Erlbaum.

Leventhal, H., Benyamini, Y., Brownlee, S., Diefenbach, M., Leventhal,E.A.,Patrick-Miller,L.\& Robitaille. 1997. Illness representations: Theoretical foundations. In Perceptions of Health and Illness, edited by Petrie, K.J. \& Weinman, J. Amsterdam: Harwood Academic. pp. 155-188.

Lok, P. 1996. Stressors, coping mechanisms and quality of life among dialysis patients in Australia. Journal of Advanced Nursing 23(5): 873-881.

Majkowicz ,M., Afeltowicz, Z. \& Lichodziejewska-Niemierko, M. 2000. Comparison of quality of life in hemodialysis (HD) and Peritoneal dialysed (CAPD) patients using the EORTC QLQ-C30) questionnaire.Int.J.Artif. Organs 23(7): 421-428.

Mapes, D.L., Lopes, A.A., Satayathum, S., Mccullough, K.P., Goodkin, D.A., Locatelli, F., Fukuhara, S., Young, E.W., Kurokawa, K., Saito, A., Bommer, J., Wolfe, R.A., Held, P.J. \& Port, F.K. 2003. Health-related quality of life as a 
predictor of mortality and hospitalization: The dialysis outcomes and practice patterns study (DOPPS). Kidney Int. 64(1): 339-349.

Merkus, M.P., Jager, K.J., Dekker, F.W., Boeschoten, E.W., Stevens, P., Krediet, R.T. \& The Necosad Study Group. 1997. Quality of life of patients on chronic dialysis: Self assessment 3 months after the start of treatment. American Journal of Kidney Diseases 29(4): 584-592.

Mittal, S.K., Aherm, L., Flaster, E., Maesaka, J.K. \& Fishbane, S. 2001. Self- assessment physical and mental function of hemodialysis patients. Nephrology Dialysis Transplantation 16(7): 1387-1394.

Moss-Morris, R., Weinman, J., Petrie, K.J., Horne, R., Cameron, L. \& Buick, D. 2002. The revised illness perception questionnaire (IPQ-R). Psychology and Health 17(1): 1-16.

Nolph, K.D. 1996. Why are reported relative mortality risk for CAPD and HD so variable?. (Inadequencies of the cox proportional hazards model). Perit. Dial. Int. 16: 15-18.

Norhayati Ibrahim, Norella Kong Chiew Thong \& Asmawati Desa. 2011. Illness perception and health-related quality of life among haemodialysis patients. Pertanika Journal of Social Sciences \& Humanities 19(S): 173-181.

Norshad, H., Sadreddini, S., Nezami, N., Salekzamani, Y. \& Aedalan, M.R. 2009. Comparison of outcome and quality of life: Haemodialysis versus peritoneal dialysis patients. Singapore Med.J. 50(2): 185-192.

Rumsfeld, J.S., MaWhinney, S., McCarthy, M., Shroyer, A.L.W., VillaNueva, C.B., O’Brien, M., Moritz, T.E., Henderson, W.G., Grover, F.L., Sethi, G.K. \& Hammermeister, K.E. 1999. Health-related quality of life as a predictor of mortality following coronary artery bypass graft surgery. JAMA 281(14): 1298-1303.

Russo, G.E., Morgia, A., Cavallini, M., Centi,A., Broccoli, M.L., Cicchinelli, A., Borzacca, B., Testorio, M. \& Pugliee, F. 2010. Quality of life assessment in patients on hemodialysis and peritonel dialysis. G Ital. Nefrol. 27(3): 290-295.

Scharloo, M., Kaptein, A.A., Weinman, J., Hazes, J.M., Breedveld, F.C. \& Rooijmans, H.G.M. 1999. Predicting functional status in patients with rheumatoid arthritis. $J$. Rheumatol. 26(8): 1686-1693.

Scharloo, M., Kaptein, A.A., Weinman, J., Bergman, W., Vermeer, B.J. \& Rooijmans, H.G.M. 2000. Patients' illness perceptions and coping as predictor of functional status in psoriasis: A 1-year follow up. Br. J. Dermatol. 142(5): 899-907.

Sensky, T. 1993. Psychosomatic aspects of end-stage renal failure. Psychother. Psychosom. 59(2): 56-68.

Timmers, L., Thong, M., Dekker, F.D., Boeschotten, E.W., Heijmans, M., Rijken, M. \& Weinman, J. 2008. Illness percreptions in dialysis patients and their association with quality of life. Psychology \& Health 23(6): 679-690.
Tucker, C.M.,Ziller, R.C., Smith, W.R., Mars, D.R.\& Coons, M.P. 1991. Quality of life of patients on in-centre hemodialysis versus continuous ambulatory peritoneal dialysis. Peritoneal Dialysis International 11(4): 341-346.

Walters, B.A., Hays, R.D. \& Spritzer, K.L. 2002. Healthrelated quality of life, depressive symptoms, anemia, and malnutrition at hemodialysis initiation. AM. J. Kidney 40: 1185-1194.

Ware, J.E., Snow, K.K., Kosinski, M. \& Gandek, B. 1993. SF-36 Health survey. Manual and Interpretation Guide. Boston: Nimrod Press.

Wasserfallen, J.B., Halabi, G. \& Saudan, P. 2004. Quality of life on chronic dialysis. Comparison between hemodialysis and peritoneal dialysis. Nephrol. Dial. Transplant 19(6): 1594-1599.

Wolcott, D.L., Nissenson, A.R. \& Lansverk, J. 1988. Quality of life in chronic dialysis patients: Factors unrelated to dialysis modality. Gen. Hosp. Psychiatry 10: 267-277.

Norhayati Ibrahim*

Health Psychology Programme, Faculty of Health Sciences

Universiti Kebangsaan Malaysia,

Jalan Raja Muda Aziz, 50300 Kuala Lumpur

Malaysia

Norella Kong Chiew-Thong

Nephrology/Dialysis and SLE Unit

Faculty of Medicine,

Pusat Perubatan Universiti Kebangsaan Malaysia (PPUKM)

Jalan Yaacob Latif, Bandar Tun Razak

56000 Cheras, Kuala Lumpur

Malaysia

Asmawati Desa \& Rozmi Ismail

School of Psychology and Human Development

Faculty of Social Sciences and Humanities

Universiti Kebangsaan Malaysia

43600 Bangi, Selangor Darul Ehsan

Malaysia

*Corresponding author; email: norhayati70@gmail.com

Received: 22 November 2013

Accepted: 17 January 2015 